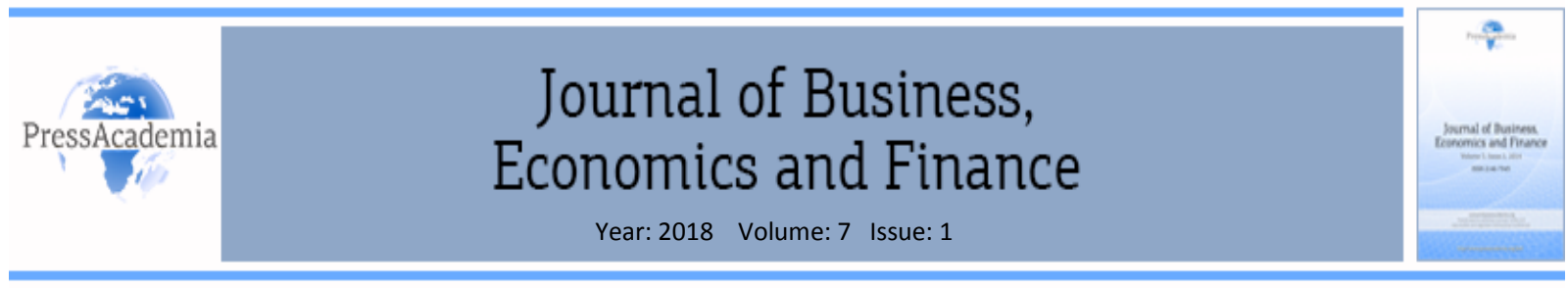

\title{
THEORETICAL STRUCTURE FOR THE APPLICATION OF STOCK-FLOW MATRIX
}

DOI: 10.17261/Pressacademia.2018.799

JBEF- V.7-ISS.1-2018(10)-p.101-113

\section{Mustafa Turhan}

Okan University, Faculty of Business and Management, Department of International Trade, İstanbul Turkey. mustafa.turhan@okan.edu.tr, ORCID: 0000-0002-7420-1652

To cite this document

Turhan, M., (2018). Theoretical structure for the application of stock-flow matrix. Journal of Business, Economics and Finance (JBEF), V.7(1), p.101-113.

Permemant link to this document: http://doi.org/10.17261/Pressacademia.2018.799

Copyright: Published by PressAcademia and limited licenced re-use rights only.

\section{ABSTRACT}

Purpose - In this study, we tried to determine the invesment goods requirements of the secttors. Stock-flow structure of the Turkish Industry analized with the help of realized investment projects.

Methodology - The sectorel investment crisis periods are determined based on the CMAX methodology and the regression analysis is applied to investiga has been used to find out how much goods and services need to build a unit capital. By this way sector by origin has been determined, this capital structure matrix was multiplied with sectorel capital-output ratios to reach stock-flow coefficients of the models.

Findings- From the results of this study it is observed that by using the the stok-flow coefficients of the sectors we come to the concisıons that is requared to invest in industry.

Conclusion- Capital coefficients are an important means to find the future location of the industries and the interrelationships of the industries as they show the relation between stock capital and current production. The capital structure matrix is associated with the SUO. This relationship is obtained by multiplying the matrix $\mathrm{K}$, which is the SUO, with the matrix $\mathrm{S}$, the stock-flow coefficient.

Keywords: Stock-flow ratio, capital stoku, Investment, production, financing and finance movements.

JEL Codes: O11, O16, D24, E22, H54

\section{INTRODUCTION}

The parameters or indicators used to determine the direction and impact of macroeconomic mobility, future status, or target status are also calculated for the real sector. The change in economic structure at macro level is used as a tool to increase profits in the sector and enterprise level and to increase production in order to increase income level in growth. For this reason, the indicators related to investments become important for both macro and micro explanations. Creating real capital in the economy occurs by converting the savings into capital goods. So investment is the essence of creating capital stock. In short, capital stock is expressed as investment in real production means added in a certain period (Barna, 1954: 254). It is a fact that capital and investment are intertwined.

Capital is a physical asset created to produce goods and services outside of it. Investment is to add capital goods (building, machinery equipment, facilities) to the capital stock, bringing the natural resources and labor. Another investment concept is the adoption of securities (stocks, treasuries and bank assumptions) as addenda (Okka, 2013: 9), but it is also not possible to accept investment in the economic sense. Labor and natural resources are used as inputs in the production of capital goods (Samuelson: 1967: 49). As macroeconomic consumption expenditures are indicative and determinative of social welfare, investment expenditures are also indicators of prosperity.

It is also the cause of the positive and negative formation of Gayrı Safi Domestic Reaction. The less or excess of investments means the growth of the macroeconomic level and the capital stock. In addition, efficiency is measured in the sector as well as in performance management. Investment in economic manpower constitutes the flow value of an country due to the capital stock, the amount of goods and services produced, and the mobility over time. The capital represents the value of the stock due to the realization of production with additional values and the stagnation. For this reason, stock and current values or coefficients show the production structure and technological development of the economy. 
At the same time, stock-flow values change depending on the production structure and technology. Stock-flow coefficients are defined as capital coefficients (Leontief, 1953: 56). The capital stock yield is obtained by dividing the capital stock by the monetary value of goods and services obtained within one year. The balance between saving and investment (Bocutoğlu, 2015: 288) and the capital-based macroeconomy is also important in the general equilibrium of the economy.

It is considered normal for developing countries to have low inventory-flow coefficients when they come to the development stage. It is observed that the stock-to-current ratios are increasing due to the decline in the capacity utilization rates that arise when the crisis starts in the economies and idle capacity is generated in the industries.

This ratio reaches normal levels with the increase in income level and the added value of technological developments. Definitions and expressions belonging to macro planning require a matrix of stock-to-current ratios. For this reason, it should be emphasized.

\section{GENERAL FRAMEWORK OF ECONOMIC GROWTH}

The increase in the value (and / or volume) of labor, capital and natural resources, which is the main element of economic development and growth, is called growth. Growth is also an expression of revenue-per-capita income. In other words, the total monetary value of goods and services produced within a year means an increase in the current production opportunities in the economy as a whole (Çetinkaya-Turk, 2014: 46).

While economic growth and economic development are sometimes used together, it is mainly meant to mean an increase in development and level of life. Development shows structural elements and socio-economic change and development. Because the expansion of the physical structure, that is to say the increase in production, brings about the expansion of the economic structure. With the increase in production, life standards and standards are improved. Personal income will increase. For this reason, growth and development, especially in some calculations, are analyzed in terms of definition and expression.

Growth is represented by symbols and is explained by mathematical equations. The first study on economic growth was initiated in 1939 by an article by Roy F. Harrod (Harrod, RF, 1939: 14), developed by Domar (Domar, 1975: 1004) and then by V. Hicks, N. Kalaldor, L .Pasinetti has been carried forward by economists dealing with growth models such as J. Robinson, RMSolow, WWRostow, R. Nurkse, HBChenery, AOHirscham.

Economic growth is difficult to analyze with mathematical models and to be in general explanations. Because variables outside the variables that are required to be used in the model are also effective on growth. The variables in the models used and their assumptions are not always the same, nor do they change or change over time. For example, the processions that are strictly tied to the pleasures and preferences (Ülgener, 1976: 456), and the changes in the targets affect the quantity and value of the production. In addition, social and political movements are also influential in economic growth (Rostow, 1966: 4).

Economic growth is difficult to analyze with mathematical models and to be in general explanations.Because variables outside the variables that are required to be used in the model are also effective on growth.

In the model studies it is possible to describe the capital and labor force with which production is related by a functional relationship. This production function determines the power, direction and technique of the relationship between inputs and outputs.

We can simply show the production function $U=f(C, L)$. It is also possible to make a mathematical definition by assuming that $U=$ Production, $C=$ Capital, $L=$ Labor produces a single commodity, and that the relationship between them is homogeneous.

In the economic literature, the relationship between production and production factors is given. The production model of Charles Cobb and Paul Douglas, which testified the period of 1899-1922 for the American economy and formulated it, was formed as follows.

$P(L, K)=b L^{\alpha} K^{\beta}$ in this model, $L=$ Labor (Annual hours worked), $K=$ Capital (production machinery, equipment, equipment, monetary value), $L=b=$ total factor productivity, $\alpha=$ output elasticity of the work, and $\beta=$ output elasticity of the capital. output elasticity of labor and capital, respectively.

These constants are determined by the current technology. Here, $\alpha$ and $\beta$ constants represent the technology used in production. Briefly, a unit of labor shows that the increase will lead to an increase in $\alpha$ in production. A unit increase in capital means that it will bring about an increase of $\beta$ on production. 
$\alpha+\beta=1$, increases in production as well as amounts of capital and labor in the production function. This is called "constant return of the production function according to the scale" (Bulutay, 1972: 29). With a 10 percent increase in labor and capital, there will be a 10 percent increase in production.

If $\alpha+\beta>1$, "increasing return by scale" means $\alpha+\beta<1$ "decreasing return by scale". The increase or decrease in production is reflected in the increases and decreases in the coefficients of labor and capital. Capital is used both by labor and by entrepreneurs. It is a tool both in production and in the creation of added value. In other words, it is wealth. It is desired to see demand from consumers as it creates added value at the end of production. This is also a factor that can be reproduced (Gold, 1957: 19). The return of the capital is the interest. In order to see the increase caused by the capital, it is necessary to know the value of the capital and the profit.

$\mathrm{CO}=$ Capital stock, $\mathrm{C} 1=$ Real capital stock, F0 = When capital gain is taken as a gain .

$$
\mathrm{C} 1{ }^{*} \mathrm{FO}
$$

$\mathrm{CO} * \mathrm{FO}$

It is possible to find the present value of the capital in terms of labor or its own derivative. For example, if labor is capitalized by dividing labor by hour (Robinson, 1956: 121), there is no weight in working hours, so it does not end very well. There are also differences in labor quality. Fixing the capital with any index, for example the average price, is not preferable because it will give an index error. For this reason capital investments are evaluated. Periodic, usually annual, fixed capital investments are added to investments that accumulate from previous periods.

In order to increase the production capacity, the capital stock is formed by the investments added to the capital. Such capital formation is defined and assessed as "gross capital" (OECD Manual, 2009: 129). These assets also cause a rise in value. For this reason, capital stock is calculated in the form of permanent inventory with the investments added annually to the capital.

\section{CALCULATION OF CHANGE RATE FOR GROWTH}

Country managers aim to improve the standards of society and increase their prosperity while making economic decisions. Increasing the welfare and the development of the standards necessitates not to value individual labor, but to accept the supremacy of law as indispensable.

On the axis of globalization, the forms of production and the conditions of competition are neither the same nor constantly changing. The stages of production in developed and developing countries affect every aspect of the macro economy. In terms of investment, saving, income, foreign trade, production styles and stages are in interaction. Technological developments and changes in the form of production force countries to determine their growth preferences and their associated dynamics.

Individuals' total potential, skilled and educated labor force, labor productivity, dynamic population structure and the tendency of this work to use technology are at the center of economic growth. These are positive variables for growth. Plan program builders make fairly stable assumptions about variables. For this reason, the past and current situation is determined and the future is tried to be formed. Care is taken to ensure that the build for the future is reasonable and feasible.

This is the opposite of strategy and policy. The strategy and model of economic growth are established by allowing for "import substitution" for the industrial sectors, for "free market economy and openness", for "tax reform and fiscal discipline", for advancing stability and for "privatization and institutional reform".

Economic growth can not be said to have played a very good role in institutional innovations, although institutional practices have to do with a range of policy reforms (Rodrik, 2009: 46). More rapid reforms are needed to accelerate growth. For growth, it is important to establish an investment strategy, expand production volume and make it productive, make new products for market dominance, use new technologies and encourage the state to encourage entrepreneurs. The state should encourage entrepreneurs-entrepreneurs and lift the production barriers in the markets. Increasing the growth rates will increase social prosperity and standards will develop. When it comes to increasing social welfare and improving standards, the determinants of the improvements in the factors, namely the supply front of the macroeconomics (Kibritcioglu, 1998: 207), have emerged. 
Decreases in the prices of labor, capital and natural resources on the supply front affect this. For example, the increase in wages and interest of these factors brings with it a cost increase. Thus, the production factors, the inputs of the producers, and the variants of the developing technologies are differentiated.

GDP also shows rational expectations with the behavioral equations of the demand-supply departments (DPTMAKROM, 2000: 2) taken as a real block in the model studies of increase or growth expression that may occur in a certain period. Increasing the income of the low-income individuals, savings and consumption habits need to be solved in a model by establishing functional and wealth relations. The resolutions also show how rational expectations (Muth, 1961: 315) will be created.

The assumption that economic growth is influential on capital stocks is revealed by mathematical studies. The periodic increase in investments is due to saving and it also influences the growth of the efficiency economy of the labor force. For example, the increase in saving rate increases labor income and transforms into investments.

The decline in investments also brings with it the decline in capital stocks. In addition, the pace of growth is volatile in relation to the increase in public spending and the tax to be applied to the private sector. Increases in public spending and increases in new supplementary taxes, which are applied on a net basis, slow economic growth.

When any economic growth rate is decided, policies are set to ensure that this speed is achieved. The amount of investment together with the policies will be calculated. Of course, what is the rate of population growth and what is important here. What is the amount of saving in response to the population increase, the answer to the questions such as the amount of savings and what the standard of living will be and how it will develop is revealed. The need for outsourcing is determined. How to increase domestic and foreign savings to reach a predicted growth rate.

It is calculated on the basis of the investments of public and private sector savings. In the face of the inadequacy of the necessary external financing resources, it is decided how the open financing policies will be implemented, the domestic borrowing or the central bank's policy of printing money. The open financing policy is brought to the agenda with the request to stimulate the economy. But it will keep the agenda on how to avoid it because it will increase public spending and trigger inflation. Because these policies have a negative impact on economic growth in real terms.

If the amount of savings can not meet the targeted amount of investment, it is necessary to reduce the growth rate. As a result of this, the amount of investment is reduced. An alternative to not reducing the amount of investment is to find external sources, to provide external assistance and to provide foreign capital entry.

17 February to 4 March 1923 Gathering of Izmir Economics Congress Mustafa Kemal Atatürk and his comrades in arms young republicans who took a very important decision for Turkey.

Mustafa Kemal, in his opening speech, "We have a new Turkey to our strong economy for us to reach the level that we are worthy of our emphasis in the first degree. Political victories no matter how big they may be victories coming crowned unless they are challenged with economic victory is not continuous. Economy means is everything, people to be happy to live that all of them are what they need for their existence "(Ökçün, 1997:209), it is possible that the state can survive not only by military victories but by applying an independent economy.According to the targets of 1923 izmir Economy Congress, "1st Industrial Development Plan" covering 1933-1938 period and "2nd Industrial Development Plan" covering 1933-1944 period were prepared.

The Democratic Party (1950-1960) period began with a search for a Democratic party plan when unplanned public spending, increasing budget deficits, uncertainties in investments, and difficulties in finding both internal and external sources came in 1959. Professor of Econometrics on world famous. Jan Tinbergen were invited to Turkey. (Turhan, 2014: 49) But this issue is kept secret. The removal of the Democratic Party Government from power by a military coup accelerated its planning efforts without further disruption.

During the military government period, the State Planning Organization (SPO) was established and the directive of economic and social life was included in the 1961 Constitution. 1960-1980 Period Turkey with political turmoil, social unrest, economic difficulties Although it had been planned and programmed with application in economics.

The "First Five-Year Development Plan", which entered into force on November 21, 1962, was published in the Official Gazette dated December 3, 1962 and accepted in the Turkish Grand National Assembly and in the Senate. Since that date, annual programs have started to be implemented. The First Five-Year Development Plan is a single sector model. This model is to determine the growth rate with Harrod-Domar.

Model; 
$g=k^{*} s_{1}\left(1-t_{d}\right) k^{*} s_{2}\left(t_{v}-t_{d}\right)+k^{*} b$

Here, $\mathrm{g}=$ Growth Rate, $\mathrm{k}=$ Marginal Capital / Output Ratio, s1 = Private Sector Saving Rate, s2 = Public Sector Saving Rate, b = Foreign Trade Deficit / National Income Rate, $\mathrm{td}=$ Taxable Taxes / National Income Rate.

In this model, the balance is like the back of a knife and its continuity is also very difficult. Homogeneity of manufactured goods and services is accepted. Economic growth depends on the amount of investment and it provides internal and external savings. Sometimes the savings goes to the consumption rather than the deposit. The production and importation of investment goods reveals how much to invest and how to allocate resources. This relationship has a positive value (Levine-Renelt, 1992: 943).

The Harrod-Domar model was used to ensure continuity of growth and to measure growth with income shots. Increases related to income are derived from the derivation of investment and saving functions. It is added to the capital stocks of the investments to be made with the portion to be provided in accordance with the investment level being equal to the savings.

If we think of investment = saving as saving, then increasing value is converted into investment, saving marginal saving tendency. The marginal saving rate and revenue will give the value of the multiplication savings. In other words, equity equality for capital stock will appear as an investment. Investment = Additional Value to Capital Stock is the Capital / Supply ratio statement.

With the Harrod-Domar model, growth is generated by capital yield ratio and saving ratio. Simply, the rate of economic growth is identified by the ratio of saving rate to capital efficiency. In other words, saving increases in the economy are proportional to economic growth.

The efficiency of capital investments will be determined by the rate of capital input efficiency of capital increase qualifications. For this reason, the relations of the productions of the sectors in the macro level are not established in the 1st Five Year Development Plan and there is no distribution of investments according to the sectors.

\section{USE IN THE PLAN MODELS OF CAPITAL / DEBT RATIO}

One of the rates used to determine the preparation of mathematical expressions of relations between variables in the models that are desired to be established in relation to economic growth is the Capital / Product Ratio (SHO). It is an evaluation unit of capital stocks and investment relations in calculating how much the national income will increase or what value should be.

Calculates the amount of investment needed to increase revenues in plan models as a unit of assessment. The investment ratio will be multiplied by the increase in the share of capital / liquidity and income. For example, if a plan model requires a $\$ 100$ billion increase in income for a given period and SHO $=4$ for this period, then an investment of $4 * 100=400$ billion dollars should be made. In other words, if SHO $=4.5$ for the same amount ( $\$ 100$ billion) of income increase, the investment amount will be 450 billion USD.

There are some difficulties in calculating and using SHO. The technological changes in external sources for capital are very fast. Technology is changing and developing very rapidly. Rapid changes in the level of technical knowledge and labor factors influence the impact on production (Alkin, 1970: 466), and it also affects these calculations.

It is assumed that the SHO used for production associations in development plans will not change during the planning period. A difficulty in SHO calculations is that the Capital / Proportion Rates calculated from previous periods are used for the plan periods after 4-5 years. The fact that stock production values are not included in the calculation is also a challenge for SHO uses. Since capital is a scarce factor, it is a matter of particular concern for developing countries. There are differences in consumption, savings and investment values among regions, annual delays, raw materials and technologies used (Çınar, 1963: 5).

Changes in spending and savings, according to changes in individual standards of living, also increase the SHO's fall. The development of infrastructure investments also changes the way they live. Investment commodities become important as this will affect the demand structure. New production techniques become necessary. The capital requirement increases as SHO grows. It should not be forgotten that capital is not the only factor in increasing production. Qualitative labor, natural resources are also important factors for production. 
The difference between the outcome of investment expenditures and the start time of the production event affects the SHO. For example, the SHO will grow because it will cause the long-term production of the investment to take place. If low capacity utilization arises after the investment is realized, SHO is also low. SHO is small if the capacity utilization is increased and the production increase is achieved before the new deposit is started.

What is to be taken as a basis for the pricing of capital and production is a distressing issue. While it is possible to bring fixed prices by using the investment index, foreign exchange control and restrictions such as reasons and bring the current price together with errors. Current prices will not be balanced. The low exchange rate makes SHOs of exports high. The change in interest rates means that the mobility in foreign exchange will change for SHO.

\section{USE OF INPUT-OUTPUT MODEL CAPACITY / DEFINITION RATIO}

It is necessary to know the relation between plan models and sectoral structures and the effects of developments. For this, input-output technique is applied in planning and directing such as investment, production, demand. In particular, it is easier to put forward this model of the relationship between the goods and services exchanges of the sectors and the final demand in the industry. This model is also used to determine the relationship between each sector and other sectors as well as the macroeconomic effect. The details of the inter-sectoral structure of the classical Input-Output Model and the instability of the parameters over time (El-Sheikh, 2011: 380). For this reason, the Input-Output Tables are used in plan models as detailed documents (Maraşlığlu-Bahçeci, 1995: 1) that reveal the sectoral production and demand structure of an economy and also show the currents of goods and services.

\subsection{Static Input-Output Technique}

Analysis of goods and services produced and purchased is done with this table. It is possible to provide supply-demand identity in the economy. In the static model, it is assumed that each goods and service is produced by a sector. Aggregations are made in the sectors. It is considered to be a single production technique. It is based on the assumption that relations are constant.

\section{Table 1: Static Input-Output Table}

\begin{tabular}{|c|c|c|c|c|c|c|c|c|c|c|c|c|}
\hline \multirow[b]{2}{*}{ Producer } & \multirow[t]{2}{*}{ User } & \multirow{2}{*}{$\begin{array}{l}\text { Demand of } \\
\text { Intermadiate goods } \\
\begin{array}{llllll}1 & 2 & 3 & . . j & \ldots . & \end{array}\end{array}$} & \multirow{2}{*}{\begin{tabular}{|c}
$\begin{array}{c}\text { Total } \\
\text { demand } \\
\text { of }\end{array}$ \\
Intermadiate \\
goods
\end{tabular}} & \multicolumn{2}{|r|}{ Final } & \multicolumn{3}{|l|}{ Demand } & \multirow{2}{*}{$\begin{array}{l}\text { Total } \\
\text { Final } \\
\text { Demand }\end{array}$} & \multirow{2}{*}{$\begin{array}{l}\text { Total } \\
\text { Supply= } \\
\text { Demand }\end{array}$} & \multicolumn{2}{|c|}{ Supp ly } \\
\hline & & & & Investment & Consumption & Export & Expenses & Stock & & & Import & Production \\
\hline & 1 & $x_{11} x_{12} x_{13} \ldots x_{1 n}$ & $\mathrm{~W}_{1}$ & $I_{1}$ & $C_{1}$ & $E_{1}$ & $\mathrm{G}_{1}$ & $\mathrm{~S}_{1}$ & $Y_{1}$ & $z_{1}$ & $M_{1}$ & $x_{1}$ \\
\hline & 2 & $x_{21} \quad x_{22} \quad x_{23} \ldots x_{2 n}$ & $W_{2}$ & $\mathrm{I}_{2}$ & $\mathrm{C}_{2}$ & $E_{2}$ & $\mathrm{G}_{2}$ & $\mathrm{~S}_{2}$ & $Y_{2}$ & $\mathrm{z}_{2}$ & $\mathrm{M}_{2}$ & $x_{2}$ \\
\hline & 3 & $x_{31} \quad x_{22} \quad x_{33} \ldots x_{3 n}$ & $W_{3}$ & $\mathrm{I}_{3}$ & $\mathrm{C}_{3}$ & $E_{3}$ & $\mathrm{G}_{3}$ & $\mathrm{~S}_{3}$ & $Y_{3}$ & $z_{3}$ & $\mathrm{M}_{3}$ & $x_{3}$ \\
\hline & . & ....... & $W_{j}$ & . & . & . & $\mathrm{G}_{\mathrm{J}}$ & $\mathrm{S}_{\mathrm{J}}$ & $Y_{j}$ & $z_{j}$ & . & . \\
\hline & $\mathrm{n}$ & $x_{n 1} \quad x_{n 2} \quad x_{n 3} \ldots x_{n n}$ & $W_{n}$ & $I_{n}$ & $C_{n}$ & $E_{n}$ & $\mathrm{G}_{\mathrm{n}}$ & $S_{n}$ & $Y_{n}$ & $z_{n}$ & $M_{n}$ & $x_{n}$ \\
\hline $\begin{array}{l}\text { Sum of Intermadiate } \\
\text { input }\end{array}$ & & $\mathrm{U}_{1} \mathrm{U}_{2} \quad \mathrm{U}_{3} \ldots \mathrm{U}_{\mathrm{n}}$ & $\mathrm{U}=\mathrm{w}$ & & & & & & & & & \\
\hline Value & & & & & & & A & & & & & \\
\hline Added & & $\begin{array}{llll}V_{1} & V_{2} & V_{3} \ldots & V_{n}\end{array}$ & & $v_{1}$ & $\mathrm{~V}_{\mathrm{c}}$ & $V_{E}$ & & $v_{S}$ & v & & & \\
\hline Total Production & & $x_{1} \quad x_{2} \quad x_{3} \ldots x_{n}$ & & 1 & C & $\mathrm{E}$ & G & $\mathrm{S}$ & Y & Z & M & $x$ \\
\hline
\end{tabular}

There are invariant parameters between modelin input and output. Tabloda Part 1 forms the basis of the relationship between sectors. Rows are input from one sector to another, and columns are the input (goods and services) that a sector receives from other sectors to maintain production. For example, $\mathrm{Xij}$ is the goods and services belonging to sector $\mathrm{i}$ requested by sector $\mathrm{j}$, column $\mathrm{i}$, i. If the aggregate intermediate demand for any sector $\mathrm{i}$ is denoted as Wi, 
$\mathrm{W}_{\mathrm{i}}=\mathrm{X}_{\mathrm{i} 1}+\mathrm{X}_{\mathrm{i} 2}+\mathrm{X}_{\mathrm{i} 3}+\ldots+\mathrm{X}_{\mathrm{ij}}+\mathrm{X}_{\mathrm{in}}=\sum \mathrm{X}_{\mathrm{ij}}$

For the total value of $j$, it is necessary to sum the elements of $y$. The sum of inputs received by one sector from other sectors is denoted by $\mathrm{U}$.

$\mathrm{U}_{\mathrm{j}}=\mathrm{X}_{1 \mathrm{j}}+\mathrm{X}_{2 \mathrm{j}}+\mathrm{X}_{3 \mathrm{j}}+\ldots+\mathrm{X}_{\mathrm{jj}}+\mathrm{X}_{\mathrm{nj}}=\sum \mathrm{X}_{\mathrm{jj}}$

The final demand elements in Table 2 are Investment, Consumption, Expenditure, Export and Stock values. In Chapter 3, labor, capital and labor payments are seen. These payments are equal to the value added to the product as a result of the production. Fees, salaries, interest payments, profits, dividends, indirect taxes and depreciation add up to value.

When calculated according to production market prices, indirect taxes are excluded from the value added value when calculated according to factor prices. In section 4, payments made to the final demand elements are included. The supply of goods or services produced by any industry is equal to the sum of imports and imports of that sector.

In the input-output current model, the representations are expressed as follows.

$X_{i j}=i$ sector item used by $\mathrm{j}$ sector

$\mathrm{X} \mathrm{i}=\mathrm{i}$ sector property

$Y_{i}=i$ sector final request

$\mathrm{Wi}=$ part of the $\mathrm{i}$ sector used in other sectors $\left(\boldsymbol{\Sigma}_{\mathrm{j}} \mathrm{X}_{\mathrm{ij}}\right)$

$\mathrm{U}_{\mathrm{j}}=$ the total intermediate input (sector) received by sector $\mathrm{j}$ from other sectors $\left(\sum_{\mathrm{i}} \mathrm{X}_{\mathrm{ij}}\right)$

$\mathrm{V}_{\mathrm{j}}=\mathrm{j}$ sector value added

It is important to establish two basic equilibrium equations.

1. Each sector is equal to the aggregate demand of total demand.

$M_{i}+X_{i}=\sum X_{i j}+Y_{i}$

$X_{i}=\sum x_{i j}+Y_{i}+Y_{i}-M_{i}$

$(i=1,2,3, \ldots n)$

2. The value of any sector is equal to the sum of inputs from the other sectors of production value plus the sum of value added.

$\mathrm{X}_{\mathrm{J}}=\sum_{\mathrm{i}} \mathrm{x}_{\mathrm{iJ}}+\mathrm{V}_{\mathrm{J}}$

( $i=1,2,3, \ldots n)$

All industry production is;

$\sum_{i} x_{i}=\sum_{i} \sum_{i} x_{i j}+\sum_{i} Y_{i}-\sum_{i} M_{i}$ occurs.

If the total production value of the sectors is;

$\sum_{\mathrm{j}} \mathrm{x}_{\mathrm{j}}=\sum_{\mathrm{j}} \sum_{\mathrm{i}} \mathrm{x}_{\mathrm{ij}}+\sum_{\mathrm{j}} \mathrm{v}_{\mathrm{j}}$ it happens.

From here, 


\section{$\sum_{\mathrm{i}} \mathrm{X}_{\mathrm{i}}-\sum_{\mathrm{i}} \mathrm{M}_{\mathrm{i}}=\sum_{\mathrm{j}} \mathrm{V}_{\mathrm{j}}$ Calculated.}

$Y$ will show GNP with $-M=V$ expression. If $G D P=I+C+G+S+E$, then $V$ is calculated as income. If there is no import in the system,

$X_{i}=\sum X_{i j}+Y_{i}$ Calculated.

Assuming that there are $\mathrm{n}$ sectors in the system and $\mathrm{n}$ final demands for them,

$X_{1}=x_{11}+x_{12}+x_{13}+\ldots \ldots x_{1 n}+Y_{1}$
$X_{2}=x_{21}+x_{22}+x_{23}+\ldots \ldots x_{2 n}+Y_{2}$
$X_{3}=x_{31}+x_{32}+x_{33}+\ldots \ldots x_{3 n}+Y_{3}$
$X_{i}=x_{i 1}+x_{i 2}+x_{i 3}+\ldots \ldots+x_{i n}+Y_{i}$
$X_{n}=x_{n 1}+x_{n 2}+x_{n 3}+\ldots \ldots+x_{n n}+Y_{n}$

Following situation will occur.

$X_{1}-x_{11}-x_{12}-\ldots \ldots \ldots-x_{1 j}-\ldots-x_{1 n}=Y_{1}$

$x_{2}-x_{21}-x_{22}-\ldots \ldots \ldots-x_{2 j}-\ldots-x_{2 n}=Y_{2}$

$x_{3}-x_{31}-x_{32}-\ldots \ldots \ldots-x_{3 j}-\ldots-x_{n n}=Y_{3}$

$X_{i}-x_{i 1}-x_{i 2}-\ldots \ldots \ldots . . . x_{i j}-\ldots-x_{i n}=Y_{i}$

$x_{n}-x_{n 1}-x_{n 2}-\ldots \ldots \ldots-x_{n j}-\ldots-x_{n n}=Y_{n}$

In the system, it is found that there are $n$ intermediate production (Xi) and $n^{*} n$ intermediate demand. Since this equation is not a system but a demand for production from any sector, it is a linear function of the production level of that sector,

$X_{i j}=a_{i j}$ When $X j$ is written, the equation $a_{i j}=X_{i j} / X_{j}$ is defined as the input coefficient. The input coefficient (aij) indicates that any sector $j$ must receive from the business sector for a unit output output.

According to this,

$\left(1-a_{11}\right) X_{1}-a_{12} X_{2}-\ldots .-a_{1 j} X_{j}-\ldots .-a_{1 n} X_{n}=Y_{1}$

$-a_{21} X_{1}+\left(1-a_{22}\right) X_{2}-\ldots .-a_{2 j} X_{j}-\ldots . .-a_{2 n} X_{n}=Y_{2}$

$-a_{i 1} X_{1}-a_{i 2} X_{2}-\ldots .+\left(1-a_{i j}\right) X_{j}-\ldots . .-a_{i n} X_{n}=Y_{i}$

$-a_{n 2} X_{1}-a_{n 2} X_{2}-\ldots .-a_{n j} X_{j}+\left(1-a_{n n}\right) X_{n}=Y_{n}$

It will be. If we show this with a matrix notation, $A=$ Input Coefficients will take the form of a matrix. Let's show the production sector matrix by $\mathrm{X}$, 


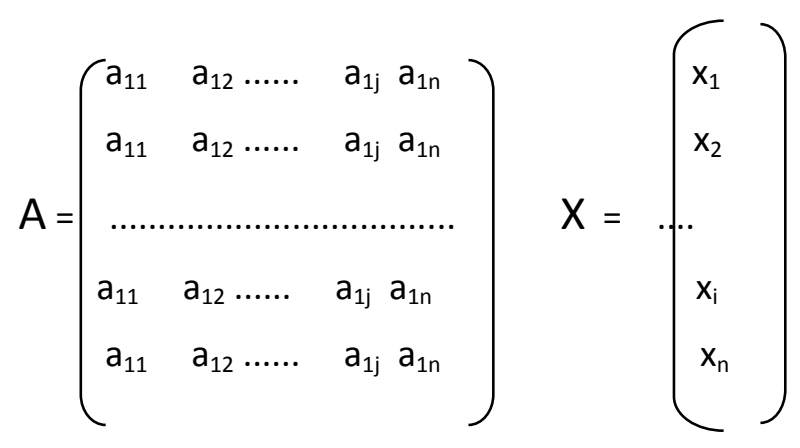

It is also possible to find the intermediate demand sector $W$ from the analysis of the following matrix

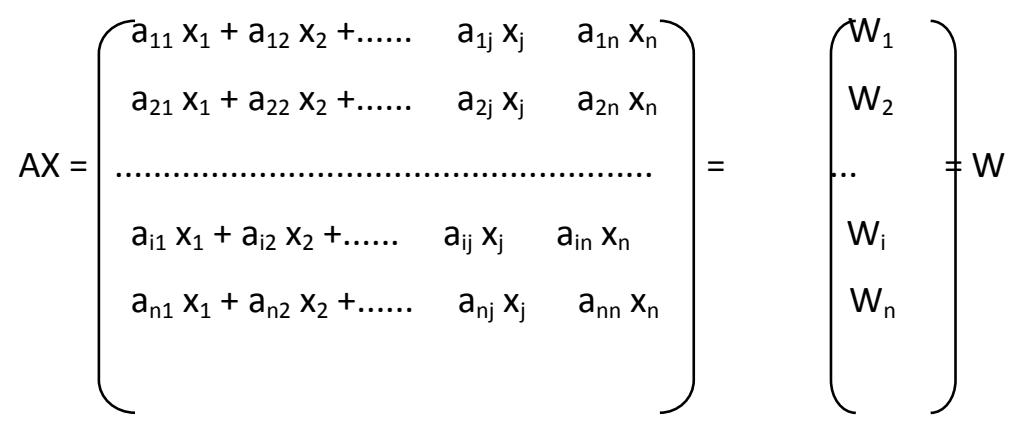

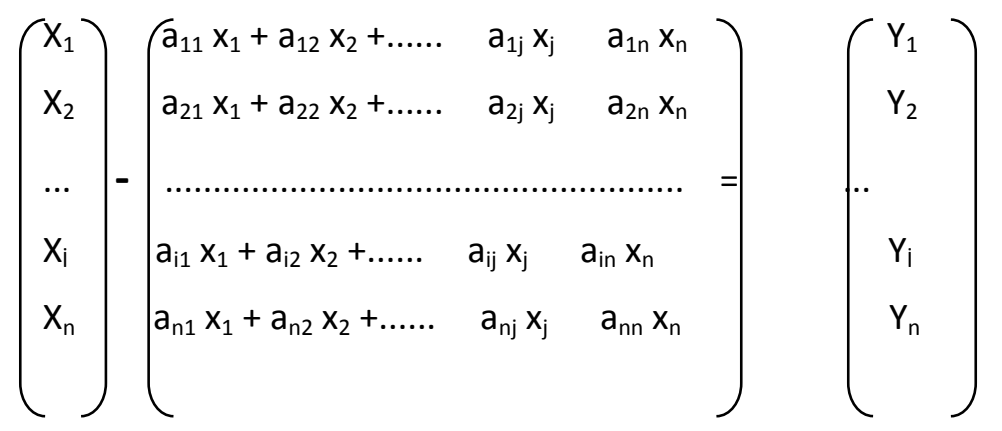

we can write the following expression.

$X-A X=Y$

If $X$ is multiplied by the unit matrix, $(1-A) X=Y$.

(1-A) $X=(1-A)-1 Y$ if each side of the equation is multiplied by the inverse of $(1-A)-A)-1(1-A)=1$, then $X=(1-A)-1 Y$ occurs.

This is also called the structural matrix of the economy (Leontief, 1973: 570). With this model, the relations between the economies of the economy and each other and the final demand are analyzed (Bocutoğlu, 1987: 223) and the structural features of the economy are tested and sectoral evaluations are made for the future.

\subsection{Dynamic Input-Output Technique}

Sectors use both input and investment goods to produce goods and services. That is, the sectoral relationship is not only in the form of input purchase, but also in the form of investment goods use. For example, if a sector has increased its final demand, this sector not only uses input-inputs but also uses investment goods. With the inclusion of the investment 
property exchange, the system becomes dynamic. In the dynamic input-output technique, there is an investment matrix showing the exchange of capital goods other than the cross-sectoral transaction matrix.

Another model of capital accumulation in this model is the stock of capital. (Chenery, 1956: 71). In a dynamic input-output model, stocks are treated as capital stock, while fixed capital and intermediate inputs are symmetrically contributed to production as compared to the previous year (Aulin-Ahmavaara, 2000: 4).

In Static Input-Output Model, it is possible to follow the changing of the parameters by observing the functions belonging to the production structure (Leontief, 1953: 53). Each sector gives a part of the goods it manufactures to the other sectors in terms of investment, in order to use it in production.

Table 2: Dynamic Input-Output Table

\begin{tabular}{|c|c|c|c|c|c|c|c|}
\hline Sectors & Flow Table & Capital Matrix & Investment & Consumption & Export & Import & Production \\
\hline 1 & $\mathrm{x}_{11} \mathrm{x}_{12} \mathrm{x}_{13 \ldots . . .} \mathrm{x}_{1 \mathrm{n}}$ & $\mathrm{S}_{11} \mathrm{~S}_{12} \mathrm{~S}_{13 \ldots . . .} \mathrm{s}_{1 \mathrm{n}}$ & $I_{1}$ & $\mathrm{G}_{1}$ & $E_{1}$ & $-\mathrm{M}_{1}$ & $X_{1}$ \\
\hline 2 & $x_{21} x_{22} x_{23 \ldots . . .} x_{2 n}$ & $S_{21} s_{22} s_{23 \ldots \ldots} s_{2 n}$ & $\mathrm{I}_{2}$ & $\mathrm{G}_{2}$ & $E_{2}$ & $-M_{2}$ & $x_{2}$ \\
\hline 3 & $x_{31} x_{32} x_{33 \ldots \ldots . . .} x_{3 n}$ & $s_{31} s_{32} s_{33} \ldots . . . s_{3 n}$ & $\mathrm{I}_{3}$ & $\mathrm{G}_{3}$ & $E_{3}$ & $-M_{3}$ & $x_{3}$ \\
\hline$\cdot$ & $\ldots$ & $\ldots \cdots \cdots \cdots \cdots \cdots \cdots \cdots \cdots \cdots$ & . & . & . & & . \\
\hline n & $x_{0} x_{0} x_{0}$ & 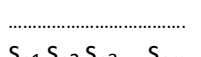 & I & $G_{1}$ & $F_{1}$ & $-M$ & $x$ \\
\hline Added & 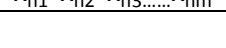 & & & & & & \\
\hline Value & $V_{1} V_{2} V_{3 \ldots \ldots} V_{n}$ & & & & & & \\
\hline Production & $x_{1} x_{2} x_{3 \ldots \ldots} x_{n}$ & $I_{1} I_{2} I_{3 \ldots \ldots . . .} I_{n}$ & I & G & $E$ & $-M$ & $x$ \\
\hline
\end{tabular}

For example, i industry's products are demanded for investment purposes in other sectors.

$\mathrm{S}_{\mathrm{i}}=\mathrm{s}_{\mathrm{i} 1}+\mathrm{s}_{\mathrm{i} 2}+\mathrm{s}_{\mathrm{i} 3}+\ldots . .+\mathrm{s}_{\mathrm{ij}}+\mathrm{s}_{\mathrm{in}}$

$\mathrm{S}_{\mathrm{i}}=\sum \mathrm{S}_{\mathrm{ij}} \quad(\mathrm{j}=1,2,3, \ldots \ldots, \mathrm{n})$

$\mathrm{S}_{\mathrm{i}}=$ total investment by $\mathrm{i}$

$s_{i j}=i$ i from sector $\mathrm{j}$ for investment $\mathrm{i}$

In the capital matrix, the sum of the order elements represents the amount of capital given by one sector to the other for investment purposes, and the capital goods that the columns receive from other sectors for investment purposes.

$S_{j}=s_{1 j}+S_{2 j}+S_{3 j}+\ldots . .+s_{i j}+s_{n j}$

$\mathrm{S}_{\mathrm{j}}=\sum \mathrm{s}_{\mathrm{ij}} \quad(\mathrm{i}=1,2,3, \ldots \mathrm{n})$

$\mathrm{S}_{\mathrm{ij}}=\mathrm{S}_{\mathrm{j}} / \delta \mathrm{K}_{\mathrm{j}}$

$\mathrm{K}_{\mathrm{j}}=$ Marginal capital value of the sector

$\mathbf{S}_{\mathrm{ij}}=$ the rate at which the unit of capital in $\mathrm{j}$ comes from which i sector.

$\sum S_{i j}=1$

The matrix that comes from the sij is S "Capital Matrix". As the capital structure is associated with production (Polat, 1979: 27), the sectoral Capital / Production Ratios (SHO) are set. There is a need for SHO to account for stock-flow coefficients. SHOs are derived from the projects of the sectors.

$\mathrm{k}_{\mathrm{j}}=\left(\delta \mathrm{K}_{\mathrm{j}} / \delta \mathrm{X}_{\mathrm{j}}\right)\left(\delta \mathrm{K}_{\mathrm{j}}=\mathrm{k}_{\mathrm{j}} \delta \mathrm{X}_{\mathrm{j}}\right.$

$\mathrm{k}_{\mathrm{j}}=$ Marginal SHO of $\mathrm{j}$ sector $\mathrm{j}$

$\delta \mathrm{K}_{\mathrm{j}}=$ Marginal investment in sector $\mathrm{j}$ (increase in capital stock)

DOI: 10.17261/Pressacademia.2018.799 
$\delta \mathrm{X}_{\mathrm{j}}=$ Marginal production growth of sector $\mathrm{j}$

The SHO is referred to as the technology coefficient here (Korum, 1963: 47). SHO refers to the relationship required for the production of a sector or industry.

$\mathrm{k}_{\mathrm{j}} \mathrm{X}_{\mathrm{j}}<\mathrm{K}_{\mathrm{j}} \mathrm{X}_{\mathrm{j}}=$ production of sector $\mathrm{j}, \mathrm{k}_{\mathrm{j}}=$ sector $\mathrm{SHO}, \mathrm{jj}=$ capital stock of sector $\mathrm{J}$.

The product of the sector and the product of the SHO is smaller than or equal to the capital stock of the sector (DervişMelo-Robinson: 1982: 66).

$\mathrm{Y}^{\mathrm{t}}=\delta \mathrm{K}_{\mathrm{j}}^{\mathrm{t}}$

$\delta \mathrm{K}_{\mathrm{j}}^{\mathrm{t}}=\mathrm{K}_{\mathrm{j}}^{\mathrm{t}+1}=\mathrm{k}_{\mathrm{j}}^{\mathrm{t}} \delta \mathrm{X}_{\mathrm{j}}^{\mathrm{t}}$

$\mathrm{Yt}=$ capital stock of the period $\mathrm{j}$ in sector $\mathrm{t}$ during period $\mathrm{t}$.

$\mathrm{Z}_{\mathrm{i}}^{\mathrm{t}}=\sum_{\mathrm{i}}^{\mathrm{n}} \mathrm{s}_{\mathrm{ij}} \delta \mathrm{K}_{\mathrm{j}}^{\mathrm{t}}$

$Z_{i}^{t}=t$ goods and services produced in the business sector

$z_{i}^{t}=\sum_{j}^{n} s_{i j} k_{j}\left(X_{j}^{t+1}-X_{j}^{t}\right)$ ocur.

$\sum_{j}^{n} s_{i j} k_{j}=\sum_{j}^{n} b_{i j} \quad$ if,

$Z_{i}^{t}=\sum_{j}^{n} b_{i j}\left(X_{j}^{t+1}-X_{j}^{t}\right)$ when,

$Z=S^{*} k\left(X^{t+1}-X^{t}\right)=B\left(X^{t+1}-X^{t}\right)$ calculated.

If the final demand is $C_{i}^{t}$ sector supply and demand balance is as follows,

$M_{i}^{t}+X_{i}^{T}=\sum_{j}^{n} a_{i j} X_{i}^{t}+\sum_{j}^{n} b_{i j}\left(X_{j}^{t+1}-X_{j}^{t}\right)+C_{i}^{t}$ occur.

The equilibrium equation of the production level of the sector, if the input coefficients are denoted by $A$, the capital coefficients are denoted by $B$,

$X^{t}=A X^{t}+B\left(X^{t+1}-X^{t}\right)+C^{t} \quad$ will be as it.

The dynamic technique should be done when the structure of the sector or economy in question is to be changed. When economic planning is needed, technological developments are associated. For this reason, it is an effective usage tool. The matrix $B$ in the dynamic model also describes the technological development (Ozaki-Shimizu, 1984: 256). This model describes both the structure of the industry and its production as well as its development. Capital accumulation and balanced growth are handled in detail (Kepenek, 1977: 56).

\section{CONCLUSION}

The SHO of industries or sectors is needed to obtain the matrix of stock-flow coefficients (capital structure matrix).

$\mathrm{S}_{\mathrm{ij}}=\mathrm{S}_{\mathrm{i}} / \partial \mathrm{K}_{\mathrm{J}} \mathrm{K}_{\mathrm{J}}=\partial \mathrm{K}_{\mathrm{J}} / \delta \mathrm{X}_{\mathrm{J}}$

Capital coefficients are an important means to find the future location of the industries and the interrelationships of the industries as they show the relation between stock capital and current production.

The capital structure matrix is associated with the SHO. This relationship is obtained by multiplying the matrix $\mathrm{K}$, which is the SHO, with the matrix $S$, the stock-flow coefficient.

$\mathrm{s}_{\mathrm{j}} \mathrm{k}_{\mathrm{J}}=\left(\mathrm{S}_{\mathrm{J}} / \delta \mathrm{K}_{\mathrm{J}}\right) *\left(\delta \mathrm{K}_{\mathrm{J}} / \delta \mathrm{X}_{\mathrm{j}}\right)=\mathrm{b}_{\mathrm{ij}}$

$\mathrm{s}_{\mathrm{ij}} \mathrm{k}_{\mathrm{j}}=\mathrm{b}_{\mathrm{ij}}$

The coefficients of bij indicate how much capital is required from the industry in order to increase unit production. 


$$
\left(\sum_{i}^{n} s_{i j}\right) / \delta x_{j}=k_{j} \quad \sum_{i}^{n} b_{i j}=k_{j}
$$

the sum of the columns of the $\mathrm{j}$ columns gives the industry's SHO (kj). Percent distribution of investments according to origin sectors will be obtained by dividing total bids by SHO (Yayın-Uras, 1971: 19), which is equal to 1.

$\left(\sum \mathrm{b}_{\mathrm{ij}}\right) / \mathrm{k}_{\mathrm{j}}=1$

By expressing the matrix of stock-flow coefficients with matrix notation

$$
\begin{aligned}
& \left.\left(\mathrm{s}_{\mathrm{ij}}\right]^{*}\left(\mathrm{k}_{\mathrm{ij}}\right]=\mathfrak{b}_{\mathrm{ij}}\right) \\
& \mathrm{S}_{\mathrm{n} * \mathrm{n}} * \mathrm{~K}_{\mathrm{n} * \mathrm{n}}=\mathrm{B}_{\mathrm{n} * \mathrm{n}}
\end{aligned}
$$

$\mathrm{S}=$ Capital structure matrix of sectors, $\mathrm{K}=$ Matrix with $\mathrm{SHO}$ in diagonal, $\mathrm{B}=$ Stock-flow coefficient matrix. With this matrix, dynamic relations of sectors are revealed. Each sector uses capital goods to both manufacture and invest. In addition to the use of capital goods for production and investment, there is also the use of service sectors. Measuring capital coefficients at certain times for industry or industry is important to reveal the direction of development. It is easier to realize the desired development structure by determining the direction in which the sectors or industries are developing. Economic growth will also facilitate the establishment of the stock-flow coefficient matrix for growth and the preparation of plans and programs to achieve the targets.

\section{REFERENCES}

Alkin, E. (1970). 1951-1971 Dönemi, Yatırım, Tasarruf ve Sermaye Hasıla Oranları. Istanbul Üniversitesi Iktisat Journal, 30( 1- 4), Page 466.

Aulin-Ahmavaara, P. (2000). Dynamic Input-Output and capital, Thirteenth International Conference in Input-Output Techniques, Macerata Italy.

Barna, T. (1954). Alternative Methods of Measuring Capital , Income and Wealth Series VIII, Editors: Raymond, G. - Sounders, G., London, Page 254-256.

Bocutoğlu, E. ve Bulut, E. (2015). 2007 Küresel Finansal Krizi: Ana Akım Konjonktür Teorilerimi Avusturyacı Konjonktür Teorisi mi. KTÜ Sosyal Bilgiler Journal, Page 285-309.

Bocutoğlu, E. (1987). Bölgesel Girdi-Çıktı Modellerinin Endüstrilerarası Sistemdeki Yeri. İstanbul Üniversitesi, Iktisat Fakültesi Journal, Cilt 43, (Prof.Dr. S.F.Ülgener'e Armagan), İstanbul, Page 223.

Bulutay, T. (1972). İktisadi Büyüme Modelleri Üzerine Açıklamalar ve Eleştiriler. A.Ü. Siyasal Bilgiler Fakültesi Publishing, No 341, Ankara. Page 29.

Çetinkaya, A.T. - Türk, E. (2014).Tasarruf ve Yatırımların Ekonomik Büyümeye Etkisi-Türkiye Örneği. Kara Harp Okulu Journal, Vol. 24.

Çınar, Ç. (1963). A Macro Model For the World. State Planning Organization Publishing, Turkey, 338.984.3.02. Ç.45.

Derviş, K.- Melo, J.D.-Robinson, S. (1982). General Equilibrıum Models for Development Policy. Cambridge Univwersity Press, Washington D.C. USA.

Domar, E.D. (1958). Essays in the Theory of Economic Growth. The American Econimic Rewiev, Vol.48, No.5, Page 1004-1009.

DPTMAKROM (2000.). SPO Publishing, No 339.5, Ankara, Page 2.

El Sheiks. S. (2011). The Structure and Determinants of Egypt's Nonagricultual Income: A Time Series Investigation. Canadian Journal of Development Studies, Page 380.

Gold,B. (1955). Foundations of Productivity Analysis. University of Pittsburg Press, , Page 29

Harrod, R.F. (1939). An Essay in Dynamic Theory. Economic Journal, Published by: Blackwell Publishing for the Royal Economic Society Vol. 49, No.193, Page 14-33.

Kepenek, Y. (1977). Türkiye İmalat Sanayinin Üretim Yapısı. ODTÜ, Ankara, Page 56.

Kibritçioğlu, A. (1998). İktisadi Büyümenin Belirleyicileri ve Yeni Büyüme Modellerinde Beşeri Sermayenin Yeri. Aü Siyasal Bilgiler Fakültesi Journal, 53, No 1-4, Page 208.

Korum, U. (1963). Input-Output Analizi. Ankara Üniversitesi Siyasal Bilgiler Fakültesi Publishingı, No 164, Ankara, Page 47. 
Leontief, W. (1978). National Income, Economic Structure and Environmental Externalities. Chapter in NBER book The Measurement of Economic and Social Performance, Editor Milton Moss, Page 570.

Leontief, W.W. (1953). Studies In the Structure of the American Economy. Oxford University Press, NewYork, Page 53.

Levine,R.-Renelt, D. (1992). A Sensitivity Analysis of Cross-Country Growth Regressions. American Economic Review, No 82 (4), Page 943. Maraşlıŏu, H. Bahçeci, S. (1995). 1993 Input-Output Tablosu RAS Yönetimi İle Tahmini. SPO, No 339.23.09561 Mar.2, Page 1.

Muth, J.F. (1961). Rational Expectations and the Theory of Price Movements. Econometrica, No 29, Page 315.

OECD (2009). Manuel, Measuring Capital, Second Edition, Page 129.

Okka, O.( 2013). Finansal Yönetim. Nobel Publishing, Ankara, Page 9.

Okpigher, S.O. (2015). The Seven Factors of Production. British Journal of Applied Science \& Technology, Vol.5( 3), Page 217.

Ozaki, I -Shimizu, M. (1984). Technological Change and the Pattern of Economic Development. Proceeding of the Seventh International Conferance on Input-Output Technique, United Nation, Page 256

Ökçün, G. (1997). Türkiye İktisat Kongresi 1923- İzmir Haberler-Belgeler-Yorumlar. SPK Publishing, No 59, 4, Page 209.

Polat, M. (1979). Türkiye Ekonomisi İçin Sermaye Yapısı Matrisinin Kurulması ve Dinamik Girdi-Çıktı Model Denemesi. DPT, Publishing, No 1676, Ankara, Page 27.

Robinson, J. (1956). The Accumulation of Capital. MacMillan Press, London, Page 121.

Rodrik, D. (2009). Tek Ekonomi Çok Recete- Küreselleşme, Kurumlar ve Ekonomik Büyüme. Translated Neşenur Domaniç, Efil Publishing, Ankara, Page 46.

Rostow, W.W. (1966). İktisadi Gelişmenin Merhaleleri. TBB Yayını, Ankara, Page 4.

Samuelson, P.A. (1976). Economics- An Intrductury Analaysis. McGraw-Hill Book Company, NewYork, Page 48-49.

Siegel, I.H. (1980). Company Productivity Measurement for Improvement. W.E. Upjohn Instutute for Employment Research, KalamazooMichigan, Page 4.

Turhan, M. (1980). Ekonomik Gelişmeler Işığında Bankalarda Örgütsel Yönetim. Beta Publishing, İstanbul, İstanbul, Page 49.

Ülgener, S.( 1976). Milli Gelir, İstihdam ve İktisadi Büyüme. Der Publishing, İstanbul, Page 456.

Yayın, S.-Uras,N.( 1971). Üçüncü Beş Yıllık kalkınma Planı Döneminin marjinal Sermaye -Üretim İlişkisi. DPT, Ankara, Page 19. 